\title{
Reflection on the FOMC Meeting of October 6, 1979
}

Joseph R. Coyne

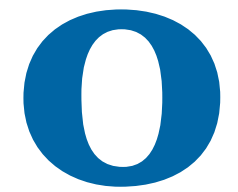

n October 6, 1979, I was one of 33

persons who attended the most defining and important meeting of the Federal Open Market

Committee (FOMC) during my more than 30 years at the Federal Reserve Board. It might well have been the most important monetary policy meeting in the entire history of the Federal Reserve System.

Inflation was on a dangerous upward curve at the time and didn't seem to be responding very well to policy actions. Chairman Volcker was especially concerned and called the special meeting that would change our lives throughout the entire System for several years to come.

Since I am not an economist, my reflections about this meeting and its aftermath don't fall under the heading of an economic treatise but involve day-to-day experiences that flowed from the meeting. They include the Pope, Gail Cincotta and consumer activists, purple hearts, two-byfours, keys, and a corporal in a John Wayne movie.

The Pope was in town at the time of the meeting and probably diverted a great deal of public attention from what was happening elsewhere in Washington. Our meeting began at 10:10 a.m. and ended a few minutes before 4 p.m., as I recall. I immediately asked the Chairman if we could have a press conference. He said yes and asked what time; I said 6 p.m.

Two of my staff and I began calling various members of the press. Keep in mind that in those days there were no cell phones or Internet. News services and newspapers were on a weekend status, and it was a quiet news day in Washington, generally, except for the Pope's visit.

Then my telephone rang. It was the chief of the CBS Washington Bureau. He said he only had one crew working that day and it was covering the Pope. He asked if our press conference was going to make big news. Without hesitating, I said he would remember the press conference long after the Pope had left town. He sent the crew and never complained. I hope the Pope has forgiven me.

The turnout at the press conference was large-more than 50 press attended, a few still in their Saturday-at-home working clothes. At one point, Irving R. Levine of NBC, apparently anxious to get the news on TV, tried to end the discussion by saying, "Thank you, Mr. Chairman." But others stopped him. They wanted more.

My next reflection is about consumer activists and, especially, Gail Cincotta. Mrs. Cincotta was from Chicago and an old-school activist for the consumer-make a lot of noise and you'll get attention.

Activist groups had scheduled a meeting in Baltimore and wanted Chairman Volcker to address them about high and rising interest rates. This is when I began to feel like the corporal in a John Wayne movie. You know, John Wayne is riding with his cavalry unit in the Old West when a group of hostile Indians appears on the horizon. Wayne says, "Corporal, take the point."

Needless to say, I wasn't too enthralled about the Chairman addressing this meeting. I discussed the invitation letter from Mrs. Cincotta with him, and he, noting that the meeting was in Baltimore, suggested that we turn for help to then President Bob Black of the Federal Reserve Bank of Richmond.

So, I telephoned President Black, and it turned out that he, too, had a corporal. He assigned one of his top officers to go to Baltimore and appear 


\section{Coyne}

at the meeting. I later received a letter from that officer explaining the rough verbal treatment he got and that he was really unable to deliver any type of reasonable speech.

That corporal later became the vice president of the new Baltimore Branch and still later was appointed president of the Federal Reserve Bank of Dallas. I like to think I was somehow instrumental in furthering Bob McTeer's career.

My turn as the corporal came quickly. Mrs. Cincotta, not soothed by events in Baltimore, brought her group to Washington. Three busloads of protesters wound up at the Board's C Street entrance and began demonstrating against high interest rates. One demonstrator wore a shark's costume- the "loan shark." I went down to negotiate with her, not by myself, mind you, but with two very tall staff economists, Peter Keir and Bob Lawrence.

She wanted the entire group to meet inside the building with the Chairman. He agreed to a meeting but with a much smaller group. After a long period of negotiation, she reluctantly cut the number to about 15 . Tensions ran high during the meeting, which lasted about 45 minutes to an hour. Afterward, Chairman Volcker went down to the C Street entrance and made some off-thecuff remarks to the crowd-with the "shark" standing nearby.

Later, Mrs. Cincotta said that, since members of the various consumer groups involved lived in various parts of the country, she would like to schedule a series of meetings with us in various cities to discuss our policies. They would select the cities and arrange the meeting sites. I thought this was a great idea because it would show our willingness to at least listen to their concerns and probably discourage them from picketing our buildings.

To make a long story short, we held the meetings and sent at least two senior officials from the Board and two from each Reserve Bank where the meetings were held. As you might expect, the meetings ranged from tense to extremely tense to sometimes threatening.

This is where the purple hearts came in. The graphics section whipped up some purple-colored pin cushions shaped like hearts and suggested they be awarded to those who had faced the verbal darts and spears that flew at the regional meetings. The Chairman himself made the presentations at a formal Board meeting.

After regional meetings in nine cities, including New York, Chicago, San Francisco, Richmond, and Des Moines, Mrs. Cincotta requested another meeting with the Chairman in Washington. He agreed, but the meeting broke up when a few of the visitors started shouting and walked out. A few days later, we awarded the Chairman a purple heart for his valiant efforts.

Next came the farmers. They had planned a march on Washington to complain about economic conditions and came complete with their tractors, parking them at the foot of Capitol Hill. We thought we were safe.

But without warning, some tractors showed up on C Street, and again the "corporal" was called. Fortunately, it was a small group of farmers, so we found a vacant conference room and invited them in. Their lawyer did most of the talking. What they wanted were low-cost loans from the Reserve Banks similar to those made by the Reserve Banks to some businesses during the Great Depression. They were turned down.

Meanwhile, the Board received hundreds, perhaps even thousands, of small pieces of lumber, each measuring exactly $2 \times 4 \times 9$ inches. They were sent by home builders and realtors, and each carried a message such as "Cut the deficit" or "Lower interest rates." NBC News took a picture of a stack of them in the Chairman's office.

Keys also arrived, representing houses that weren't being built and cars that weren't being sold. One Congressman delivered a big batch of keys, which Governor Partee received on behalf of the Board. He then presented the Congressman with a cardboard sword, made by our graphics section, with the inscription "Cut the Deficit." Governor Partee, incidentally, also attended the regional meeting in Chicago and received one of the purple hearts.

As you can see from all this, the effects of the 1979 meeting were widespread throughout the country. The number of stories that could be told are almost endless. So let me close with some 
reflections about two trips to Las Vegas that still stick in my mind.

During the period of high interest rates following the 1979 FOMC meeting, the Chairman made a trip to Las Vegas to address the annual convention of the National Association of Home Builders. Although the home building market was extremely weak, the delegates gave him a polite reception and even two standing ovations.

The realtors were in equally bad shape at that time, but, a few years later, delegates to the annual convention of the National Association of Realtors gave the Chairman a resounding standing ovation when he walked into the convention hall.

That applause was just one indication of the results that grew from the procedures adopted by the FOMC at its meeting of October 6, 1979. That meeting planted the seed that eventually broke the back of inflation and laid the groundwork for the period of economic growth that we have enjoyed-with little or no inflation-over the past two decades. 
